\title{
DOPUSZCZALNOŚĆ PRZEPROWADZENIA ROZPRAWY POD NIEOBECNOŚĆ OSKARŻONEGO LUB OBROŃCY NA PODSTAWIE ART. 378A K.P.K. W KONTEKŚCIE KONSTYTUCYJNEGO PRAWA DO OBRONY
}

\begin{abstract}
Abstrakt: Nowelizacją z 19 lipca 2019 roku wprowadzono do kodeksu postępowania karnego art. 378a, który dopuszcza możliwość przeprowadzenia rozprawy oraz podjęcie czynności dowodowych pod nieobecność oskarżonego i obrońcy, również, gdy nieobecność ta ma charakter usprawiedliwiony. Ta regulacja, mająca w założeniu usprawnić przebieg postępowania, budzi jednak daleko idące wątpliwości, zważywszy na konstytucyjne prawo do obrony. Celem opracowania jest analiza zgodności wprowadzonej zmiany w art. 42 ust. 2 oraz art. 31 ust. 3 ustawy zasadniczej, a także wskazanie konsekwencji wprowadzenia omawianego przepisu względem procesu stosowania prawa.
\end{abstract}

Słowa kluczowe: prawo do obrony, oskarżony, zasada proporcjonalności, prawo do obecności, dostęp do adwokata

\section{WPROWADZENIE}

Ustawą z dnia 19 lipca 2019 roku$^{1}$ dokonano kolejnej obszernej nowelizacji kodeksu postępowania karnego, której celem, jak wynika z uzasadnienia przedstawionego przez projektodawcę, jest usprawnienie przebiegu postępowania karnego, a także zapobieżenie obstrukcji procesowej dokonywanej przez strony. Jedną z wprowadzonych przez nowelizację zmian, która w założeniu ma realizować wymienione postulaty, jest dodanie do obowiązującej treści kodeksu art. 378a. Przepis ten w $\S 1$ przewiduje możliwość przeprowadzenia w szczególnych wypadkach postępowania dowodowego, w tym przesłuchania świadków, podczas nieobecności zarówno oskarżonego, jak i obrońcy, co jest szczególnie istotne, nawet jeżeli ma ona charakter usprawiedliwiony. Artykuł w $\S 3$ zastrzega następnie prawo oskarżonego lub obrońcy do złożenia wniosku o uzupełniające przeprowadzenie

1 Ustawa z dnia 19 lipca 2019 roku o zmianie ustawy - Kodeks postępowania karnego oraz niektórych innych ustaw, Dz.U. z 2019 r. poz. 1694. 
dowodu, przeprowadzonego podczas jego usprawiedliwionej nieobecności, najpóźniej na kolejnym terminie rozprawy, o którym był prawidłowo zawiadomiony przy jednoczesnym niezaistnieniu procesowych przeszkód do jego stawiennictwa. Z § 5 i 6 artykułu wynika natomiast, że wniosek powinien zostać oparty na wykazaniu naruszenia gwarancji procesowych oskarżonego, w tym w szczególności prawa do obrony przez sposób przeprowadzenia dowodu — i w tym zakresie sąd będzie rozpatrywał jego zasadność.

Unormowanie to budzi jednak wiele wątpliwości², zarówno ze względu na konstytucyjne prawo do obrony, jak i wiele aktów o charakterze międzynarodowym i unijnym, mających za przedmiot prawo do aktywnego udziału oskarżonego w postępowaniu oraz problematykę dostępu do adwokata ${ }^{3}$.

\section{STANDARD GWARANCYJNY PRAWA DO OBRONY}

Prawo do obrony, zgodnie z ugruntowanym stanowiskiem doktryny, stanowi podstawowe uprawnienie wchodzące w skład pojęcia rzetelnego procesu oraz prawa do sądu ${ }^{4}$. Na poziomie międzynarodowym jest ono zagwarantowane zarówno w ramach uniwersalnego systemu ochrony praw człowieka przez art. 14 Międzynarodowego paktu praw obywatelskich i politycznych ${ }^{5}$, jak i na gruncie systemu regionalnego, przede wszystkim w art. 6 ust. 3 Konwencji o ochronie praw człowieka i podstawowych wolności ${ }^{6}$ oraz art. 47 i $48 \mathrm{Karty}_{\text {praw podstawowych }}^{7}$.

2 Zob. między innymi uwagi Sądu Najwyższego do projekty ustawy o zmianie ustawy Kodeks postępowania karnego oraz niektórych innych ustaw, z dnia 12 marca 2019 roku, http:// orka.sejm.gov.p1/Druki8ka.nsf/0/F5BF27E91FA57F7DC12583C3002E9D24/\%24File/3251-002. pdf, (dostęp: 5.11.2020).

3 Zob. wniosek RPO do Prezydenta RP o zaskarżenie do TK zmian w Kodeksie postępowania karnego, https://www.rpo.gov.pl/sites/default/files/Pismo\%20do\%20Prezydenta\%20RP\%20z\%20 wnioskiem $\% 20 \mathrm{o} \% 20$ zakar\%C5\%BCenie $\% 20 \mathrm{do} \% 20 \mathrm{TK} \% 20 \mathrm{zmian} \% 20 \mathrm{w} \% 20$ Kodeksie $\% 20$ post \%C4\%99powania\%20karnego.pdf (dostęp: 5.11.2020).

${ }^{4}$ W literaturze w różny sposób ujmuje się relację prawa do sądu i rzetelnego procesu. Niektórzy przedstawiciele doktryny wskazują, że prawo do rzetelnego procesu jest pojęciem szerszym, odnosząc sie niejako do struktury art. 6 EKPC, inni rzetelność utożsamiają z wąsko rozumianą rzetelnością (sprawiedliwością) proceduralną, stanowiącą część składową prawa do sądu. W jednym ze swoich wyroków TK wskazał z kolei, że oba pojęcia stanowią w zasadzie tożsame uprawnienie. Zob. wyrok TK z 15 kwietnia 2008 roku, P 26/06, OTK-A 2008, nr 3, poz. 42; J. Skorupka Sprawiedliwość proceduralna jako cel procesu karnego, [w:] Rzetelny proces karny. Księga jubileuszowa Profesor Zofii Świdy, red. J. Skorupka, Warszawa 2009, s. 69; J. Pradel, Rzetelny proces w europejskim prawie karnym, „Prokuratura i Prawo” 1996, nr 9, s. 10.

${ }^{5}$ Międzynarodowy pakt praw obywatelskich i politycznych otwarty do podpisu w Nowym Jorku dnia 19 grudnia 1966 roku, Dz.U. z 1977 r. Nr 38, poz. 167.

${ }^{6}$ Konwencja o ochronie praw człowieka i podstawowych wolności z dnia 4 listopada 1950 roku, Dz.U. z 1993 r. Nr 61, poz. 284 (dalej: Konwencja).

7 Karta praw podstawowych Unii Europejskiej, Dz.Urz. UE C 326 (dalej: Karta). 
W obrębie unijnego porządku prawnego ochrona prawa do obrony w ostatnich latach została znacząco wzmocniona wprowadzeniem szeregu dyrektyw, objętych tak zwanym programem sztokholmskim ${ }^{8}$, którego celem jest zapewnienie zbliżonego poziomu gwarancyjnego w przestrzeni wolności bezpieczeństwa i sprawiedliwości, a tym samym usprawnienie współpracy wymiarów sprawiedliwości w sprawach karnych ${ }^{9}$.

Na gruncie krajowego systemu prawnego podstawowe źródło prawa do obrony stanowi Konstytucja RP ${ }^{10}$. Artykuł 42 ust. 2 polskiej ustawy zasadniczej wskazuje, że każdy, przeciw komu prowadzone jest postępowanie karne, ma prawo do obrony we wszystkich stadiach postępowania. W drugim zdaniu ustrojodawca wskazuje natomiast, że podmiot uprawniony może w szczególności wybrać obrońcę lub na zasadach określonych w ustawie korzystać z obrońcy z urzędu. Konstytucyjny standard prawa do obrony obejmuje tym samym przyznanie stronie biernej procesu karnego ${ }^{11}$ prawa do obrony, zarówno w znaczeniu materialnym, jak i formalnym ${ }^{12}$.

Biorąc pod uwagę problematykę zakresu prawa do obrony, która w analizie omawianej regulacji może stanowić punkt odniesienia w dalszej części opracowania, należy zauważyć, że kwestią szczególnie relewantną będzie w tym wypadku przedstawienie zakresu przedmiotowego tego prawa. Zakres podmiotowy oraz temporalny prawa do obrony, jakkolwiek wciąż pozostaje aktualnym, nierozwiązanym przez polskiego ustawodawcę, problemem, podnoszonym zarówno w doktrynie, jak i orzecznictwie Trybunału Konstytucyjnego, nie może w wypadku art. 378a k.p.k. budzić wątpliwości interpretacyjnych, jako że artykuł ten znajduje zastosowanie jedynie na etapie postępowania sądowego. Status oskarżonego natomiast, jako pełnoprawnego podmiotu zarówno konstytucyjnego prawa do obrony, jak i prawa na poziomie międzynarodowym, jest statusem powszechnie uznanym i wolnym od jakichkolwiek kontrowersji.

\subsection{PRAWO DO OBRONY W ZNACZENIU MATERIALNYM}

Konstytucyjne prawo do obrony w swojej istocie umożliwia oskarżonemu swobodę wyboru zachowania podczas procesu w granicach określonych przepisami. Swoboda ta może polegać na możliwości albo aktywnego uczestnictwa w postępowaniu i w tym zakresie podejmowaniu określonego rodzaju działań, albo

${ }^{8}$ Program sztokholmski - Otwarta i bezpieczna Europa dla dobra i ochrony obywateli, Dz.Urz. UE C 115.

9 Zob. art. 67 ust. 4 Traktatu o funkcjonowaniu Unii Europejskiej, Dz.Urz. UE C 326.

10 Konstytucja RP z dnia 2 kwietnia 1997 roku, Dz.U. z 1997 r. Nr 78, poz. 483 ze zm.

11 Odnośnie do pojęcia strony biernej procesu zob. J. Skorupka, Proces karny, Warszawa 2018, s. 301.

12 P. Wiliński, P. Karlik, komentarz do art. 42 ust. 2 Konstytucji, [w:] Konstytucja RP, t. 1. Komentarz art. 1-86, red. M. Safjan, L. Bosek, Warszawa 2016, s. 1049-1061. 
zachowania biernego oraz prawa domagania się respektowania wolności od samooskarżenia przez organy postępowania ${ }^{13}$. Dla przedmiotu rozważań kluczowe znaczenie będzie mieć zespół uprawnień, zorientowany wokół wyboru przez oskarżonego czynnego działania $w$ ramach procesu, ściśle powiązany z prawem do obrony w znaczeniu materialnym, a więc możliwością podejmowania działań zmierzających do odparcia zarzutów stawianych oskarżonemu za pomocą nadanych mu praw procesowych $^{14}$.

Prawo do obrony ujęte w ten sposób, przewidując możliwość efektywnego wpływania na własną sytuację w postępowaniu, nadaje oskarżonemu status aktywnego podmiotu procesowego. Zgodnie z ugruntowanym stanowiskiem Trybunału Konstytucyjnego prawo do obrony nie może być prawem iluzorycznym, ale przez odpowiednie ukształtowanie zespołu instytucji procesowych i zapewnienie właściwej praktyki stosowania prawa powinno być ono uprawnieniem efektywnym i skutecznym ${ }^{15}$. Oskarżonemu przysługuje wobec tego pewien zbiór uprawnień, takich jak prawo do informacji, dostępu do materiału dowodowego, korzystania z pomocy tłumacza, możliwość składania wyjaśnień, wnoszenia wniosków dowodowych, a także prawo udziału w czynnościach procesowych ${ }^{16}$.

Ostatni z wymienionych elementów, jak można $\mathrm{z}$ łatwością zauważyć, szczególnie przyczynia się do powstania wątpliwości odnośnie do zasadności wprowadzenia regulacji art. 378a k.p.k. Należy przede wszystkim zaznaczyć, że zarówno Sąd Najwyższy, jak i Trybunał Konstytucyjny, odnosząc się do treści art. 42 ust. 2 Konstytucji, wskazywały, że prawo do udziału w posiedzeniach sądu jest uprawnieniem procesowym o charakterze podstawowym i jednocześnie jest warunkiem skutecznej realizacji prawa do obrony w wymiarze materialnym ${ }^{17}$, szczególnie w przypadku podejmowania czynności dowodowych ${ }^{18}$. Prawo do obecności oskarżonego Trybunał Konstytucyjny powiązał z obowiązkiem zapewnienia efektywności prawa $z$ art. 42 ust. 2 ustawy zasadniczej, a także samego prawa do sądu. Trybunał zaznaczył, że nie może być mowy o rzetelnie ukształtowanej procedurze

13 B. Nita, Konstytucyjne zakorzenienie zasady nemo tenetur se ipsum accusare, [w:] Rzetelny proces karny..., s. 220-234; P. Wiliński, Zasada prawa do obrony w polskim procesie karnym, Kraków 2006, s. 267-274.

14 P. Wiliński, Proces karny w świetle Konstytucji, Warszawa 2011, s. 177-179.

15 C. Kulesza, Efektywność udziatu obrońcy w procesie karnym w perspektywie prawnoporównawczej, Kraków 2005, s. 204-207; wyrok TK z dnia 28 listopada 2007 roku, K 39/07, OTK-A 2007, nr 10, poz. 129; wyrok TK z dnia 25 listopada 2014 roku, K 54/13 OTK-A 2014, nr 10, poz. 114; wyrok TK z dnia 11 grudnia 2012 roku, K 37/11, OTK-A 2012, nr 11, poz. 133.

16 P. Wiliński, op. cit., s. 174-177; A. Lach, Rzetelne postępowanie dowodowe w sprawach karnych $w$ świetle orzecznictwa strasburskiego, Warszawa 2018, s. 112-158; wyrok TK z 17 maja 2004, SK 32/03, OTK-A nr 5, poz. 44.

17 Wyrok TK z dnia 6 grudnia 2004 roku, SK 29/04, OTK-A 2004, nr 11, poz. 114; wyrok TK z dnia 17 lutego 2004 roku, SK 39/02, OTK-A 2004, nr 7 poz. 2; wyrok SN z dnia 24 lutego 2003 roku, IV KK 379/02, Lex, nr 75448.

18 Wyrok SN z dnia 9 grudnia 2002 roku, V KK 18/02, niepubl. 
sądowej, jeżeli oskarżony zostaje pozbawiony możliwości przedstawiania swoich racji, żądań, wniosków, a także polemizowania ze stroną przeciwną, zgodnie z założeniami kontradyktoryjnego procesu karnego ${ }^{19}$. Na tej podstawie można zatem wysnuć jednoznaczny wniosek, że uprawnienie oskarżonego do obecności przy podejmowanych w trakcie postępowania sądowego czynnościach dowodowych jest nieodłącznym elementem skutecznego prawa do obrony.

Podobne stanowisko można odnaleźć w orzecznictwie sądów międzynarodowych. ETPCz wielokrotnie podkreślał znaczenie, jakie dla realizacji prawa do rzetelnego procesu i prawa do obrony w znaczeniu materialnym ma udział samego oskarżonego w posiedzeniach i rozprawach, a także zapewnienie rzeczywistej skuteczności tego uprawnienia ${ }^{20}$. Trybunał uznał między innymi konieczność zapewnienia obecności oskarżonego na rozprawie, w tym zwłaszcza przy wszelkich czynnościach dowodowych, dla efektywnej realizacji przysługującego mu w ramach art. 6 ust. 3 lit. c EKPC prawa do obrony osobistej, a także dla realizacji podstawowych założeń rzetelnego procesu w postaci równouprawnienia stron procesowych oraz efektywnego prawa do sądu ${ }^{21}$.

Bogate orzecznictwo TSUE odnoszące się do tej kwestii, wyrażające stanowisko zbliżone do poglądu strasburskiego, zostało natomiast bezpośrednio usankcjonowane na drodze postanowień dyrektywy 2016/343 w sprawie wzmocnienia niektórych aspektów domniemania niewinności i prawa do obecności podczas procesu w postępowaniu karnym ${ }^{22}$. Dyrektywa w art. 8 ust. 1 wprost przyznaje oskarżonemu prawo do obecności na rozprawie, przewidując tym samym generalny obowiązek wobec organów państwa umożliwienia oskarżonemu wzięcia w niej udziału. Jednocześnie w ust. 2 wprowadza możliwość zastrzeżenia ściśle określonych wyjątków w tym zakresie, stanowiąc, że sprawa sądowa, której wynikiem może być orzeczenie w przedmiocie winy lub niewinności oskarżonego, może odbyć się pod jego nieobecność, pod warunkiem że powiadomiono go we właściwym czasie o rozprawie, jak również o konsekwencjach niestawiennictwa, lub oskarżony, którego poinformowano o rozprawie, jest reprezentowany przez umocowanego obrońcę.

19 Wyrok TK z dnia 20 października 2010 roku, P 37/09, OTK-A 2010, nr 8, poz. 79. Zob. też J. Zagrodnik et al., komentarz do art. 378a, [w:] Kodeks postepowania karnego. Komentarz praktyczny do nowelizacji 2019, red. J. Zagrodnik, Warszawa 2020, s. 140-145.

${ }^{20}$ Zob. wyroki ETPCz w sprawach: Pakelli przeciwko Niemcom z dnia 25 kwietnia 1983 roku, nr skargi 8398/78; Goddi przeciwko Włochom z dnia 9 kwietnia 1984 roku, nr skargi 8966/80; Artico przeciwko Włochom z dnia 13 maja 1980 roku, nr skargi 6694/74.

21 Wyrok ETPCz z dnia 19 grudnia 1989 roku w sprawie Kamasinski przeciwko Austrii, nr skargi, 9783/82, § 106; wyrok ETPCz z dnia 23 czerwca 1993 roku, w sprawie Ruiz-Mateos przeciwko Hiszpanii, nr skargi 12952/87.

22 Dyrektywa Parlamentu Europejskiego i Rady (UE) 2016/343 z dnia 9 marca 2016 roku w sprawie wzmocnienia niektórych aspektów domniemania niewinności i prawa do obecności na rozprawie w postępowaniu karnym, Dz.Urz. UE L 65. 
Biorąc pod uwagę pierwszy z wymienionych warunków, należy założyć, że dyrektywa dopuszcza tutaj możliwość przeprowadzenia rozprawy tylko wtedy, jeżeli oskarżony — prawidłowo zawiadomiony i zaznajomiony z konsekwencjami - świadomie i ze swojej winy nie stawił się na procesie. Taki wniosek wynika z analizy preambuły dyrektywy, która stanowi, że jeżeli z przyczyn niezależnych od oskarżonego nie jest on w stanie stawić się na rozprawie, powinien mieć w takim wypadku możliwość zwrócenia się o wyznaczenie nowego terminu postępowania, $w$ trybie przewidzianym przez przepisy krajowe ${ }^{23}$.

Drugi z przedstawionych w artykule wymogów odnosi się z kolei do sytuacji, w której w czynnościach sądu uczestniczy obrońca. Nieobecność oskarżonego jest tutaj niejako rekompensowana przez zapewnienie prawa do obrony formalnej i umożliwienie obrońcy podejmowania czynnego udziału w postępowaniu. Prawodawca unijny przyjmuje tym samym, że oskarżony, który mimo prawidłowego zawiadomienia nie uczestniczy na przykład w czynnościach dowodowych, nie zostanie narażony na uszczerbek jego praw procesowych jedynie wtedy, gdy jego uprawnienia będzie mógł realizować jego przedstawiciel w postępowaniu.

Wszystkie wymienione źródła, zarówno w postaci aktów prawnych, jak i orzecznictwa wyznaczającego kierunek interpretacji co do ich zasadniczej treści, kształtują pewien standard w zakresie materialnego prawa do obrony. Jego nieodłączny element stanowi niewątpliwie prawo do obecności oskarżonego na rozprawie, mające zapewnić skuteczność i efektywność pozostałych przysługujących mu uprawnień. Każda regulacja ograniczająca prawo oskarżonego do udziału w posiedzeniach sądu, zwłaszcza w przypadku postępowania dowodowego, będzie tym samym stanowić ograniczenie prawa do obrony w znaczeniu materialnym.

\subsection{PRAWO DO OBRONY W ZNACZENIU FORMALNYM}

Rozważania przedstawione w punkcie poprzednim, zwłaszcza w odniesieniu do postanowień dyrektywy 2016/343, jednoznacznie wskazują, że w celu dokonania oceny zgodności wprowadzonej przez polskiego ustawodawcę regulacji, konieczne jest również dokonanie analizy konstytucyjnego prawa do obrony w znaczeniu formalnym, czyli prawa do skorzystania $\mathrm{z}$ fachowej pomocy przedstawiciela procesowego w postaci obrońcy z wyboru lub z urzędu ${ }^{24}$.

${ }^{23}$ Należy również podkreślić, że dyrektywa, za każdym razem do przeprowadzenia w jakimkolwiek wypadku rozprawy pod nieobecność oskarżonego wymaga w tym zakresie potwierdzenia jego prawidłowego zawiadomienia. Wobec tego, gdy doszło do jakichkolwiek nieprawidłowości w tym zakresie, przeprowadzenie rozprawy pod nieobecność oskarżonego jest absolutnie niedopuszczalne. Dyrektywa w swojej preambule zaznacza ponadto wagę prawa w stosunku do obecności oskarżonego na toczącej się rozprawie, wywodząc je z zasady rzetelnego procesu i podkreślając, że jego zapewnienie jest elementem koniecznym w demokratycznym państwie prawnym. Zob. pkt 33 i 34 preambuły dyrektywy 2016/343.

24 P. Wiliński, op. cit., s. 177-179. 
Istotą obrony formalnej jest możliwość aktywnej reprezentacji oskarżonego przez zapoznanie się ze stanem faktycznym, ustalenie linii obrony w porozumieniu z klientem oraz ostatecznie - przeprowadzenie obrony na rozprawie ${ }^{25}$. Rola obrońcy sprowadza się zarówno do aktywnego uczestnictwa w czynnościach procesowych, szczególnie w postępowaniu dowodowym, jak i możliwości kontroli przebiegu procesu, prawidłowości czynności dokonywanych między innymi na rozprawie oraz zgłaszania wszelkich zastrzeżeń w tym zakresie, na które będzie mógł się również powołać przed sądem drugiej instancji ${ }^{26}$. Należy zauważyć, że obrońca, który nie ma sposobności udziału w czynnościach dowodowych, w tym w przesłuchaniu świadków, zostaje pozbawiony możliwości zadawania pytań czy też składania zastrzeżeń do protokołu, a tym samym rzeczywistego wpływania na tok postępowania dowodowego oraz kontroli czynności sądu pod kątem jego prawidłowego przebiegu. Jeżeli zatem istotą obrony formalnej ma być aktywny udział obrońcy w procesie, sytuację, w której ogranicza się w znacznym zakresie możliwość jego udziału w czynnościach sądu, trudno uznać za spełniającą standard efektywnego prawa do obrony wedle art. 42 ust. 2 Konstytucji.

Również w przypadku obrony formalnej standardy konstytucyjne znajdują potwierdzenie w orzecznictwie strasburskim i prawodawstwie unijnym. ETPCz nie tylko uznał prawo do uczestnictwa $\mathrm{w}$ rozprawie za nieodłączny element prawa do obrony, lecz także wskazał, że to po stronie organów postępowania leży w znacznej mierze obowiązek zapewnienia tejże obecności. Zgodnie z utrwaloną linią orzeczniczą Trybunału adwokatowi przysługuje uprawnienie do bycia prawidłowo zawiadomionym o zaplanowanej rozprawie, a także o innych czynnościach procesowych, $\mathrm{w}$ jakich, zgodnie $\mathrm{z}$ regulacjami krajowymi i międzynarodowymi, ma prawo wziąć udział ${ }^{27}$. Trybunał w swoich orzeczeniach wskazał między innymi na to, że w gestii sądu leży zawiadomienie obrońcy ustanowionego przez oskarżonego o rozprawie, natomiast niedopełnienie tego obowiązku może stanowić wyłączną przesłankę odpowiedzialności państwa ${ }^{28}$. W dalszej kolejności na organach państwowych spoczywa obowiązek umożliwienia adwokatowi faktycznego wzięcia udziału w czynnościach podejmowanych przez te organy w trakcie postępowania $^{29}$. Co istotne, Trybunał w jednym ze swoich orzeczeń wprost uznał

25 Zob. C. Kulesza, Znaczenie udziału i uprawnienia obrońcy w postępowaniu sądowym, [w:] System Prawa Karnego Procesowego, t. 6. Strony i inni uczestnicy postępowania karnego, red. C. Kulesza, Warszawa 2016, s. 952; J. Waszczyński, O przygotowaniu obrony, „Palestra” 1966, nr 8, s. 23-30.

${ }^{26}$ C. Kulesza, Efektywność obrońcy w procesie karnym i jej kodeksowe uwarunkowania, [w:] System Prawa Karnego Procesowego, t. 6. Strony i inni uczestnicy postępowania karnego, red. C. Kulesza, s. 929.

27 Zob. między innymi wyrok ETPCz z dnia 9 kwietnia 1984 roku w sprawie Goddi przeciwko Włochom, nr skargi 8966/80.

28 B. Rainey, E. Wicks, C. Ovey, The European Convention on Human Rights, Oxford 2017, s. 320 .

29 Ibidem, s. 321. Por. wyroki w sprawach Artico; Poitrimol, § 38; z 11 grudnia 2008 roku w sprawie Panovits przeciwko Cyprowi, nr skargi 4268/04, § 99. 
za niedopuszczalną sytuację, w której sąd odmówił odroczenia rozprawy apelacyjnej mimo wniosku adwokata pozbawionego możliwości obecności na posiedzeniu ze względu na niezależne od siebie wypadki losowe ${ }^{30}$.

Pośrednio do problematyki prawa obrońcy do czynnego udziału w rozprawie odnosi się również dyrektywa 2013/48/UE w sprawie prawa dostępu do adwokata $^{31}$. Dyrektywa, w znacznej mierze potwierdzając wcześniejsze orzecznictwo TSUE wydane na podstawie art. 47 Karty ${ }^{32}$, w swojej zasadniczej treści zawiera postanowienia określające, $w$ jakich sytuacjach oskarżonemu lub podejrzanemu przysługuje prawo do adwokata, a także w jakiego rodzaju czynnościach ma on prawo wzięcia udziału. Dotychczas większość kontrowersji w obszarze regulacji dyrektywy pojawiała się na gruncie postępowania przygotowawczego i dokonywania przez organy ścigania czynności dochodzeniowo-śledczych bez obecności adwokatów. Natomiast w związku z wprowadzeniem do kodeksu postępowania karnego art. 378a wątpliwości przenoszą się również na grunt postępowania sądowego.

Dyrektywa już w preambule zaznacza, że państwa członkowskie zobowiązane są do zapewnienia obecności adwokata w określonych czynnościach dowodowych, które mogą wpływać na dalszy tok postępowania. Ponadto zastrzega również, że samej obecności adwokata nie można uznać za wystarczającą do realizacji założeń prawa do obrony, i przewiduje, że adwokat między innymi podczas rozprawy sądowej może zadawać pytania, domagać się wyjaśnień i składać oświadczenia, co powinno zostać zaprotokołowane zgodnie z prawem krajowym.

Biorąc pod uwagę przedstawione regulacje, należy zauważyć, że zarówno na poziomie krajowym, jak i międzynarodowym, ograniczenie prawa obrońcy do udziału w posiedzeniach sądu jest ingerencją w prawo do obrony. Jeżeli zatem ingerencja ta będzie mieć charakter nieproporcjonalny lub nieuzasadniony, będzie to przesądzać o naruszeniu standardu konstytucyjnego, konwencyjnego oraz unijnego.

30 Ibidem, wyrok ETPCz z dnia 9 kwietnia 2015 roku w sprawie Vamvakas przeciwko Grecji, nr skargi 2870/11.

31 Dyrektywa Parlamentu Europejskiego i Rady 2013/48/UE z dnia 22 października 2013 roku w sprawie prawa dostępu do adwokata w postępowaniu karnym i w postępowaniu dotyczącym europejskiego nakazu aresztowania oraz w sprawie prawa do poinformowania osoby trzeciej o pozbawieniu wolności i prawa do porozumiewania się z osobami trzecimi i organami konsularnymi w czasie pozbawienia wolności, Dz.Urz. UE L 294.

32 Zob. między innymi wyroki TSUE z dnia 22 października 2010 roku, w sprawie DEB Deutsche Energiehandels- und Beratungsgesellschaft mbH przeciwko Republice Federalnej Niemiec, C-279/09; z dnia 14 września 2009 roku, w sprawie Akzo Nobel Chemicals i Akcros Chemicals przeciwko Komisji, C-550/07; wyroki ETS z 18 maja 1982 roku, w sprawie AM \& S Europe Limited przeciwko Komisji, C-155/79; z dnia 4 kwietnia 1990 roku, w sprawie Hilti AG przeciwko Komisji, T-30/89. 


\section{PROPORCJONALNOŚĆ OGRANICZEŃ}

Prawo do obrony w ujęciu konstytucyjnego prawa podmiotowego nie ma oczywiście charakteru absolutnego i może podlegać ograniczeniom. Należy jednak mieć na uwadze, że ograniczenia praw i wolności muszą odpowiadać wymaganiom określonym w art. 31 ust. 3 Konstytucji RP. Trybunał Konstytucyjny w swoim orzecznictwie wypracował pewien katalog warunków, które mają być każdorazowo spełnione, aby postulowane ograniczenie zawierało się w ramach wyznaczonych przez zasadę proporcjonalności. Przede wszystkim, wprowadzona regulacja, zgodnie ze stanowiskiem Trybunału, ma doprowadzić do zamierzonych przez nią skutków, być wymaganą w celu ochrony interesu publicznego, któremu służy, a jej korzyści nie mogą odbiegać od odpowiedniej proporcji w stosunku do nakładanych przez nią ciężarów - czyli spełnić odpowiednio wymogi celowości, niezbędności oraz proporcjonalności sensu stricto ${ }^{33}$. Spełnienie tych wymogów jest także konieczne dla zapewnienia poszanowania standardów europejskich $w$ ramach zasady proporcjonalności ${ }^{34}$. Analiza omawianego przepisu pozostawia natomiast wiele wątpliwości pod kątem czynienia zadość wymienionym warunkom.

\subsection{CELOWOŚĆ}

$\mathrm{Z}$ analizy uzasadnienia projektu ${ }^{35} \mathrm{~W}$ części dotyczącej omawianego przepisu jasno wynika, że wprowadzając tego rodzaju zmianę, ustawodawca kierował się chęcią zapobieżenia przedłużaniu toczących się postępowań przez strony procesu w wyniku nadużywania przez nie praw podmiotowych i doprowadzania do konieczności odraczania rozpraw, tym samym zmierzając do zapewnienia realizacji zasady szybkości postępowania.

Artykuł 45 ust. 1 Konstytucji RP, a także art. 6 ust.1 Konwencji o ochronie praw człowieka i podstawowych wolności niewątpliwie zobowiązuje organy po-

33 Zob. między innymi wyroki TK z 9 lipca 2009 roku, SK 48/05, OTK-A 2009, nr 7, poz. 108; z dnia 14 lipca 2015 roku, SK 26/14, OTK-A z 2015 roku, nr 7, poz. 101; z 4 listopada 2015 roku, K 1/14, OTK-A z 2015 roku, nr 10, poz. 163; L. Garlicki, K. Wojtyczek, komentarz do art. 31 Konstytucji, [w:] Konstytucja Rzeczypospolitej Polskiej. Komentarz, red. L. Garlicki, M. Zubik, t. 2, Warszawa 2016, s. 69 n.; P. Tuleja, komentarz do art. 31 Konstytucji, [w:] Konstytucja Rzeczypospolitej Polskiej. Komentarz, red. P. Tuleja, Warszawa 2019, s. 114-119; B. Banaszak, Konstytucja Rzeczypospolitej Polskiej. Komentarz, Warszawa 2012, s. 212.

34 T. Barkhuysen et al., Right to a fair trial, [w:] Theory and Practice of the European Convention on Human Rights, red. P. van Dijk et al., Cambridge 2018, s. 637; wyrok ETPCz z dnia 6 września 2007 roku w sprawie Kijewska przeciwko Polsce, nr skargi 73002/01, § 46; wyrok TSUE z dnia 9 listopada 2010 roku w sprawie Volker und Markus Schecke GbR i Hartmut Eifert przeciwko Land Hessen, C-92/09 i C-93/09, § 74; wyrok TSUE z dnia 13 listopada 2014 roku w sprawie Ute Reindl przeciwko Bezirkshauptmannschaft Innsbruck, C 443/13, pkt 40.

35 Uzasadnienie rządowego projektu ustawy o zmianie ustawy - Kodeks postępowania karnego oraz niektórych innych ustaw, http://orka.sejm.gov.pl/Druki8ka.nsf/0/A617BC771FDAE09 5C12583AC004875E9/\%24File/3251-uzas.docx (dostęp: 5.11.2020), s. 1-2, 42. 
stępowania do dążenia do rozpoznania sprawy bez zbędnej zwłoki i w rozsądnym terminie. W literaturze kwestia przewlekłości postępowań nadal uznawana jest za problem aktualny ${ }^{36}$, a rolą prawodawcy jest bezsprzecznie ukształtowanie procesu w taki sposób, aby zapewnić jak najsprawniejszy jego przebieg, doprowadzając do skutecznej realizacji jego celów.

Przede wszystkim należy jednak podkreślić, że zasada szybkości postępowania karnego nie może być utożsamiana jedynie z samym czynnikiem czasu, zawierając się tym samym $\mathrm{w}$ prostym postulacie ukończenia postępowania $\mathrm{w}$ jak najkrótszym terminie, ale winna być wiązana z wymogami składającymi się na konstrukcję ujmowaną w doktrynie jako zasada sprawności postępowania ${ }^{37}$. W swoim założeniu opiera się ona głównie na znaczeniu funkcjonalnym, zapobiegając przedłużającej się reakcji państwa na czyn zabroniony i opóźnieniom w realizacji celów procesu karnego ${ }^{38}$. W głównej mierze ma ona zatem sprzyjać budowaniu zaufania obywateli do państwa jako struktury zapewniającej efektywne działanie władzy sądowniczej. Wprowadzając regulacje, które przez swoim charakterem podważają istotę tego zaufania, ustawodawca dokonuje wobec tego naruszenia podstawowych założeń, leżących u podłoża zasady sprawności postępowania, podając w wątpliwość zasadność ich ustanowienia ${ }^{39}$.

Kwestią zasługującą również na podkreślenie w kontekście zasady zaufania obywateli do państwa jest sama konstrukcja wniosku o uzupełniające przeprowadzenie dowodu. Zakłada ona nie tylko całkowite przerzucenie ciężaru dowodowego na oskarżonego, który zobowiązany jest do wykazania podstaw wniosku, to jest domniemanego naruszenia praw procesowych, ale de facto także obowiązku dbania o prawidłowy przebieg postępowania. Obowiązek ten, zgodnie z modelem przyjętym w polskim procesie karnym, spoczywa na organach prowadzących postępowanie, a więc biorąc pod uwagę etap, którego dotyczy zakres temporalny art. $378 \mathrm{a}$, na sądzie ${ }^{40}$. Takie rozwiązanie, szeroko aprobowane i przywoływane

36 Zob. między innymi D. Szumiło-Kulczycka, Zasada sprawności (szybkości) i zasada koncentracji materiału dowodowego, [w:] System Prawa Karnego Procesowego, t. 3, cz. 2. Zasady procesu karnego, red. P. Wiliński, Warszawa 2014, s. 939; J. Czapska, S. Waltoś, Zagubiona szybkość procesu karnego. Jak ja przywrócić?, Warszawa 2005.

37 D. Szumiło-Kulczycka, op. cit., s. 948-949.

38 Ibidem, s. 947.

39 Analizując tę problematykę chociażby z punktu widzenia samych celów procesu karnego, można dojść do konkluzji, że szybkość rozumiana jako czysto techniczny aspekt procesu, który ma sprowadzać się do ukończenia postępowania w jak najkrótszym czasie kosztem zespołu przepisów prowadzących w założeniu do trafnej reakcji karnej, skutkuje w istocie naruszeniem celu procesu w postaci choćby osiągnięcia sprawiedliwości proceduralnej. Zob. P. Wiliński, Sprawiedliwość proceduralna a proces karny, [w:] Rzetelny proces karny..., s. 81; J. Skorupka, Cele procesu karnego, [w:] System Prawa Karnego Procesowego, t. 1, cz.1. Zagadnienia ogólne, red. P. Hofmański, Warszawa 2013, s. $177-178,182$.

40 G. Artymiak, Pojęcie sądu i rodzaje sądów, [w:] System Prawa Karnego Procesowego, t. 5. Sady i inne organy postepowania karnego, red. Z. Kwiatkowski, Warszawa 2015, s. 197. 
w orzecznictwie ETPCz ${ }^{41}$, niewątpliwie sprzyja realizacji omawianej zasady. Treść brzmienia $\S 5$ art. 378a jednoznacznie wskazuje natomiast, przyjmując za zasadniczą przesłankę wniosku naruszenie prawa do obrony, na obarczenie oskarżonego oraz jego obrońcy koniecznością czuwania nad prawidłowością toku postępowania i zapewnienia stronom ich słusznych praw procesowych, czym jednocześnie przyczynia się do osłabienia zaufania stron do sądu jako organu prowadzącego postępowanie, a nawet co do jego bezstronności.

Ponadto należy również zauważyć, że wprowadzenie art. 378a w obecnym brzmieniu niekoniecznie doprowadzi do znacznego przyspieszenia postępowania i ograniczenia nakładu pracy organów procesowych. Przede wszystkim trudno wyobrazić sobie, że obrońca, w przypadku przeprowadzenia dowodu pod jego usprawiedliwioną nieobecność spowodowaną jakimkolwiek niezawinionym wypadkiem losowym, nie skorzysta $\mathrm{z}$ uprawnienia przewidzianego $\mathrm{w} \S 3$ art. 378a. Należy również wskazać, że każde przeprowadzenie dowodu w takich warunkach będzie $\mathrm{w}$ istocie naruszeniem prawa do obrony, zważywszy na treść i zakres tego prawa przedstawiony powyżej. Z analizy omawianego artykułu, w tym w szczególności § 6, wynika zatem, że sąd w przypadku usprawiedliwionej nieobecności każdorazowo będzie zobowiązany do uwzględnienia wniosku i uzupełniającego przeprowadzenia dowodu. Wobec tego ponownie dochodzi do obciążenia kosztami stawiennictwa, konieczności powtórnego stawienia się świadków, a ponadto rozpatrzenia przedstawionego wniosku i ostatecznie przeprowadzenia dowodu po raz kolejny.

Wreszcie, rozpatrując w szerszym kontekście zagadnienie celu omawianej nowelizacji i podkreślanej przez projektodawcę konieczności realizacji zasady sprawności postępowania, wątpliwości budzi również konsekwencja ustawodawcy w tym zakresie. Analizując rozwiązania systemowe poszczególnych państw europejskich, należy zauważyć, że jednym z podstawowych środków służących usprawnieniu przebiegu postępowania karnego jest dopuszczenie możliwości istnienia trybów konsensualnych ${ }^{42}$. Natomiast zgodnie z orzecznictwem Trybunału Konstytucyjnego nie można przyznać regulacji przymiotu celowości, jeżeli ustawodawca dokonuje działań stojących „w poprzek jej założeń”, wykazując się tym samym brakiem spójności we wprowadzanych przepisach ${ }^{43}$. Biorąc zatem pod uwagę likwidację trybów konsensualnych przeprowadzoną przez ustawodawcę

${ }^{41}$ ETPCz w swoim orzecznictwie odnoszącym się w szczególności do prawa do obrony wskazywał, że to rolą organu prowadzącego postępowanie jest czuwanie nad prawidłową realizacją tego prawa, dbanie między innymi o prawidłowe zawiadomienie stron i obrońcy, pouczanie o przysługujących prawach procesowych i reagowanie na wszelkie odstępstwa od konwencyjnego standardu. Zob. M.A. Nowicki, Wokót Konwencji Europejskiej. Komentarz do Europejskiej Konwencji Praw Człowieka, Warszawa 2017, s. 611-612; Agencja Praw Podstawowych Unii Europejskiej i Rada Europy, Podręcznik prawa europejskiego, dotyczacego dostępu do wymiaru sprawiedliwości, Luksemburg 2016, s. 74-77.

42 D. Szumiło-Kulczycka, op. cit., s. 970.

43 M. Szydło, Komentarz do art. 31, [w:] M. Safjan, L. Bosek, op. cit., s. 793-794. 
nowelizacją z dnia 11 marca 2016 roku, wątpliwość budzi racjonalność ustawodawcy w dążeniu do osiągnięcia celu w postaci sprawnej realizacji założeń procesu karnego, a tym samym uczynienie zadość wymogom art. 31 ust. 3 Konstytucji.

\subsection{NIEZBĘDNOŚĆ}

Kolejną kwestią wymagającą wyjaśnienia jest odpowiedź na pytanie, czy wprowadzenie omawianej regulacji jest działaniem koniecznym i wskazanych przez ustawodawcę celów nie sposób osiągnąc za pomocą odmiennych środków. Przede wszystkim należy zatem zidentyfikować konkretny problem, który przyświecał włączeniu art. 378a do przepisów kodeksowych. W szerokim ujęciu jest to — jak zostało wcześniej wskazane — przyspieszenie przebiegu postępowania. Do ścisłych motywów projektodawcy należy natomiast zaliczyć przede wszystkim zapobieżenie obstrukcji procesowej, wywoływanej umyślnym działaniem stron procesowych. $Z$ treści uzasadnienia do projektu nowelizacji wynika, że zarówno oskarżony, jak i obrońca w sposób zamierzony nie stawiają się na rozprawę w celu przedłużenia toku postępowania, przedstawiając jednak stosowne zaświadczenia dokumentujące niemożność stawiennictwa i usprawiedliwiając swoją nieobecność, powodując tym samym konieczność odroczenia posiedzenia. Ustawodawca, dążąc do wyeliminowania wskazanych praktyk, dopuścił wobec tego możliwość przeprowadzenia postępowania dowodowego nawet przy usprawiedliwionej nieobecności zarówno oskarżonego, jak i jego obrońcy, zabezpieczając ochronę przed naruszeniem prawa do obrony jedynie w postaci wniosku o ponowne przeprowadzenie dowodu ${ }^{44}$.

Należy jednak zauważyć, że ustawa przyjmuje tym samym mechanizm polegający na generalnym dopuszczeniu przez przepisy kodeksu postępowania karnego sytuacji naruszenia praw procesowych oskarżonego, które może zostać ewentualnie konwalidowane na skutek wniosku oskarżonego lub jego obrońcy, opierając jednocześnie tę konwalidację na uznaniu sądu orzekającego. Jakkolwiek ustawodawca przy tworzeniu przepisów zobowiązany jest uwzględnić realia toczących się postępowań i wszelkie nieprawidłowości pojawiające sie w ich toku, to jednak kierowanie się przy kreowaniu nowych regulacji założeniem o domniemanej nieuczciwości stron procesowych i potraktowanie jej jako zasady, do której należy dostosować rzeczywistość prawną oraz ograniczanie przy tym słusznych, uznanych zarówno przez ustawę zasadniczą, jak i standardy międzynarodowe praw podmiotowych, budzi poważne wątpliwości z punktu widzenia prawidłowości podejmowanych środków prawodawczych.

44 Projektodawca wprost wskazuje w uzasadnieniu na znaczne ryzyko naruszenia prawa do obrony. Ponadto w samej konstrukcji wniosku o uzupełniające przeprowadzenie postępowania dowodowego można zauważyć również to, że ustawodawca przewiduje wystąpienie naruszenia tego prawa. 
Wydaje się natomiast, że jeżeli ustawodawca upatruje problem w nadużywaniu przydanych stronom praw procesowych, powinien skoncentrować swoje działania legislacyjne w obszarze źródeł tychże nadużyć, w tym między innymi dopuszczając szerszą kontrolę dokumentów usprawiedliwiających nieobecność stron na rozprawie. Państwo dysponuje szerokim aparatem administracyjno-kontrolnym, zdolnym do nadzoru w zakresie prawidłowości przedstawianych okoliczności wyjaśniających niestawiennictwo. Przy jednoczesnym obowiązku potwierdzenia zaświadczeniem niemożności obecności przy czynności procesowej przez lekarza sądowego, wynikającego z art. 117 § 2a k.p.k. skuteczność takiej kontroli przedstawia się jako założenie osiągalne. Środek w postaci uprzedniego dopuszczenia naruszenia prawa do obrony wydaje się w związku z tym wychodzić poza założenia wymogu niezbędności.

\subsection{PROPORCJONALNOŚĆ SENSU STRICTO}

Niewątpliwie zasadą, wobec której ustawodawca dokonuje w świetle wymogu proporcjonalności wzajemnego zestawienia korzyści i ograniczeń z materialnym i formalnym prawem do obrony z art. 42 ust. 2 Konstytucji, jest szybkość postępowania. Reguła szybkości ze swojej istoty może w pewnych sytuacjach pozostawać w opozycji do szeregu innych zasad procesowych ${ }^{45}$, w tym między innymi do zasad prawdy materialnej, bezpośredniości czy wreszcie - prawa do obrony, powodując tym konieczność ich wzajemnego wyważenia. Jakkolwiek wątpliwości budzić może pogląd o każdorazowo drugorzędnym charakterze postulatu sprawności przebiegu procesu ${ }^{46}$, trudno jednak przyznać omawianej zasadzie absolutny prymat nad chociażby rzetelnym zebraniem materiału dowodowego czy podstawowymi gwarancjami procesowymi stron. Zasada szybkości postępowania, choć niewątpliwie istotna dla prawidłowości jego toku, w żadnej mierze nie może jednak prowadzić do naruszenia standardu rzetelnego procesu ${ }^{47}$.

Prawo do obrony jest natomiast kluczowym elementem prawa do rzetelnego postępowania $^{48}$. Stanowi warunek realizacji zasady równości broni, kontradyktoryjności i skutecznego prawa do sądu. Jeżeli zatem w obecności na rozprawie upatruje się nieodłącznego elementu prawa do obrony — a, jak to zostało wskazane, zgodnie z ugruntowanym stanowiskiem doktryny szybkość postępowania nie może naruszać gwarancji prawa do rzetelnego procesu — to dopuszczenie moż-

45 D. Szumiło-Kulczycka, op. cit., s. 994.

46 Por. J. Haber, Podstawowe zasady procesu karnego w świetle projektu kodeksu postępowania karnego, „Państwo i Prawo” 1969, z. 2, s. 204; P. Kruszyński, Sprawność postępowania sądowego. Dyskusja w Redakcji „Państwa i Prawa”, „Państwo i Prawo” 1974, z. 7, s. 122.

47 Ibidem; D. Szumiło-Kulczycka, op. cit., s. 995-1000.

48 I. Nowikowski, Uwagi o zasadzie rzetelnego procesu (kwestie wybrane), [w:] Rzetelny proces karny..., s. 48-49; W. Daszkiewicz, Prawo karne procesowe. Zagadnienia ogólne, Poznań 1999, s. 70-71; A. Murzynowski, Istota i zasady procesu karnego, Warszawa 1994, s. 55. 
liwości przeprowadzenia czynności dowodowych na rozprawie pod nieobecność zarówno obrońcy, jak i oskarżonego, przez powołanie się właśnie na zasadę szybkości, należy przyjąć jako naruszenie wymogu proporcjonalności sensu stricto. Wydaje się, że korzyści, które projektodawca zamierzał osiągnąć, wprowadzając omawianą regulację, w żadnej mierze nie można uznać za upoważniające do narażenia słusznych gwarancji procesowych stron na tak daleko idące konsekwencje, wskazane już w zakresie prawa do obrony. Oczywiście rolą sądu jest, zgodnie $\mathrm{z}$ art. 45 ust. 1 ustawy zasadniczej, dążenie do rozpatrzenia sprawy w rozsądnym terminie i bez zbędnej zwłoki, jednak realizacja postulatu szybkości postępowania nie może każdorazowo uzasadniać ograniczenia praw stron w procesie, zwłaszcza w tak dużym stopniu.

W tym zakresie należy również zauważyć, że powoływanie się w uzasadnieniu na podobieństwo unormowań obowiązujących na gruncie kodeksu postępowania w sprawach o wykroczenia wydaje się argumentem wielce wątpliwym. Przede wszystkim nie sposób nie zauważyć różnic w ciężarze gatunkowym spraw rozpatrywanych w obu rodzajach postępowań oraz możliwych dla stron konsekwencji wynikających z końcowego orzeczenia, co będzie ostatecznie skutkowało innym rozkładem korzyści i ograniczeń w ramach omawianej zasady ${ }^{49}$.

\subsection{ISTOTA PRAWA DO OBRONY}

Należy pamiętać, że zgodnie z treścią art. 31 ust. 3 Konstytucji RP ograniczenia dotyczące praw i wolności nie mogą naruszać ich istoty ${ }^{50}$. Nawiązując do analizy dokonanej w poprzedniej części artykułu, można wskazać, że istotą materialnego prawa do obrony jest uczynienie z oskarżonego aktywnego podmiotu procesowego, wyposażonego w prawnie zagwarantowaną możliwość udziału w czynnościach procesowych i wpływania na ich przebieg. Formalny aspekt prawa jest $\mathrm{z}$ kolei nieodłącznie związany $\mathrm{z}$ czynnym udziałem obrońcy $\mathrm{w}$ trakcie postępowania, a punkt kulminacyjny jego działalności — $\mathrm{z}$ etapem rozprawy właśnie, w której przez podejmowanie aktywnej obrony może znacząco wpływać na przeprowadzane postępowanie dowodowe. Wydaje się zatem, że w przypadku pozbawienia możliwości udziału w rozprawie i przeprowadzanych w jej trakcie czynności dowodowych zarówno oskarżonego, jak i obrońcy, gdy mamy do czynienia z nieobecnością niezawinioną i należycie usprawiedliwioną, dochodzi do naruszenia istoty prawa do obrony.

49 Należy zauważyć, że wiele aktów o charakterze unijnym lub międzynarodowym przewiduje wyłączanie ze swojego zakresu przedmiotowego tak zwanych drobnych przestępstw.

50 M. Szydło, op. cit., s. 801; wyroki TK z 12 stycznia 2000 roku, P. 11/98, OTK z 2000 roku, nr 1, poz. 3; z 12 stycznia 1999 roku, P 2/98, OTK z 1999 roku, nr 1, poz. 2. 


\section{PODSUMOWANIE}

Biorąc pod uwagę wszystkie wymienione argumenty, należy stwierdzić, że omawiana regulacja znacząco ingeruje w konstytucyjne prawo do obrony. Zestawiając standard konstytucyjny z art. 42 ust. 2 oraz art. 31. ust. 3 ustawy zasadniczej z wykreowanym przez art. 378a k.p.k. stanem prawnym, stwierdzić można, że przepis budzi poważne wątpliwości, w kontekście prawa do obrony zarówno w znaczeniu materialnym, jak i formalnym. Dopuszczając możliwość przeprowadzenia posiedzenia oraz czynności dowodowych podczas usprawiedliwionej nieobecności zarówno oskarżonego, jak i obrońcy, wyraźnie narusza się standard gwarancyjny wypracowany na gruncie obu aspektów konstytucyjnego prawa, przejawiający się w prawie do obecności i uczestniczenia w postępowaniu dowodowym wymienionych podmiotów. Co więcej, regulacja nie wydaje się czynić zadość wymogom celowości, niezbędności oraz proporcjonalności. Godzi również w samą istotę efektywnego prawa do obrony, przesądzając tym samym o swojej niekonstytucyjności.

Warto przy tym zauważyć, że standard gwarancyjny przewidziany w Konstytucji RP w znacznej mierze pokrywa się ze standardem rzetelnego procesu ujętego w orzecznictwie ETPCz oraz prawie unijnym. Regulacje zawarte zarówno w orzecznictwie strasburskim, jak i wielu dyrektywach nie stoją w sprzeczności z treścią ustawy zasadniczej, jedynie mogą służyć klarowaniu jej postanowień, wyprowadzając z klauzul generalnych konkretne prawa podmiotowe. Natomiast jak wynika z ich postanowień, prawo do obecności i aktywnego udziału w czynnościach dowodowych jest niezbędnym i nieodłącznym elementem efektywnego prawa do obrony; z kolei regulacja polskiego kodeksu postępowania karnego we wskazanym kształcie w sposób jeszcze bardziej jednoznaczny narusza stawiane przez nie wymogi.

W związku z tak poważnymi wątpliwościami natury konstytucyjnej, a także sformułowaniem przepisu wskazującym na jedynie fakultatywną możliwość zastosowania art. 378a k.p.k., sądy powinny powstrzymać się od stosowania omawianych regulacji w praktyce podejmowania czynności procesowych. W zakresie procesu stosowania prawa powinno się również wskazać na szczególną rolę źródeł międzynarodowych, w tym przede wszystkim prawa unijnego. Wobec braku implementacji ${ }^{51}$ dyrektywy 2016/343 organy postępowania zobowiązane są do respektowania tak zwanego skutku pośredniego aktu, to jest automatycznej niestosowalności, w innym wypadku narażając państwo na odpowiedzialność odszkodowawczą. Na postanowienia dyrektywy może również powołać się bezpośrednio strona postępowania, żądając odmowy zastosowania art. 378a k.p.k. lub wystąpienia z pytaniem prawnym do TSUE.

51 Termin implementacji upłynął 1 kwietnia 2018 roku, zgodnie z art. 14 dyrektywy. 
Wreszcie powinno się zaznaczyć, że zastosowanie regulacji może jednocześnie stanowić względną przyczynę odwoławczą z art. 438 § 2 k.p.k. Jak wskazują J. Zagrodnik oraz D. Świecki, naruszenie przepisów postępowania może polegać nie tylko na naruszeniu przepisów k.p.k., lecz także na naruszeniu prawa wtórnego $\mathrm{UE}^{52}$. Jeżeli zatem samo odwołanie się do przepisów konstytucyjnych można uznać za niewystarczające i zbyt ogólne, to prawo unijne można uznać za wystarczająco konkretne źródło uprawnień i reguł procesowych. Zatem w przypadku przeprowadzenia rozprawy pod nieobecność zarówno oskarżonego, jak i jego obrońcy, a następnie wskazania, że uchybienie przepisom mogło mieć wpływ na treść orzeczenia, oskarżony będzie mógł podnieść stosowny zarzut w drugiej instancji.

\title{
ADMISSIBILITY OF HOLDING A HEARING IN THE ABSENCE OF THE DEFENDANT AND DEFENCE COUNCEL PURSUANT TO ARTICLE 378A OF THE CRIMINAL PROCEDURE CODE IN THE CONTEXT OF THE CONSTITUTIONAL RIGHT TO DEFENCE
}

\author{
Summary
}

The amendment from 19th July 2019 introduced to the criminal procedure code article 378a, which allows conducting the trial and the hearing of evidence in the absence of both defendant and defence councel, also in the event that the absence is excused. This regulation, whose intended purpose was to streamline the course of proceedings, raises far-reaching concerns, taking into account the constitutional right to defence. The aim of the study is to analyse the compliance of the introduced amendment with article 42 section 2 and article 31 section 3 of the Constitution, as well as to indicate the consequences of introducing the provision in relation to the process of applying law.

Keywords: right to defence, defendant, principle of proportionality, right to be present, access to lawyer

\section{BIBLIOGRAFIA}

Agencja Praw Podstawowych Unii Europejskiej i Rada Europy, Podręcznik prawa europejskiego, dotyczacego dostęu do wymiaru sprawiedliwości, Luksemburg 2016.

Artymiak G., Pojęcie sądu i rodzaje sądów, [w:] System Prawa Karnego Procesowego, t. 5. Sądy i inne organy postępowania karnego, red. Z. Kwiatkowski, Warszawa 2015.

Banaszak B., Konstytucja Rzeczypospolitej Polskiej. Komentarz, Warszawa 2012.

Czapska J., Waltoś S., Zagubiona szybkość procesu karnego. Jak ja przywrócić?, Warszawa 2005. Daszkiewicz W., Prawo karne procesowe. Zagadnienia ogólne, Poznań 1999.

Garlicki L., Wojtyczek K., [w:] Konstytucja Rzeczypospolitej Polskiej. Komentarz, red. L. Garlicki, M. Zubik, t. 2, Warszawa 2016.

52 D. Świecki et al., komentarz do art. 438, [w:] Kodeks postępowania karnego, t. 2. Komentarz aktualizowany, red. D. Świecki, Warszawa 2020; J. Zagrodnik, Obrońca i petnomocnik w procesie karnym i karnym skarbowym, Warszawa 2020, s. 507. 
Haber J., Podstawowe zasady procesu karnego w świetle projektu kodeksu postępowania karnego, „Państwo i Prawo” 1969, z. 2.

Kodeks postepowania karnego, t. 2. Komentarz aktualizowany, red. Świecki D., Warszawa 2020.

Kruszyński P., Sprawność postępowania sądowego. Dyskusja w Redakcji „Państwa i Prawa”, „Państwo i Prawo” 1974, z. 7.

Kulesza C., Efektywność obrońcy w procesie karnym i jej kodeksowe uwarunkowania, [w:] System Prawa Karnego Procesowego, t. 6. Strony i inni uczestnicy postępowania karnego, red. C. Kulesza, Warszawa 2016.

Kulesza C., Efektywność udziału obrońcy w procesie karnym w perspektywie prawnoporównawczej, Kraków 2005.

Kulesza C., Znaczenie udziału i uprawnienia obrońcy w postępowaniu sądowym, [w:] System Prawa Karnego Procesowego, t. 6. Strony i inni uczestnicy postepowania karnego, red. C. Kulesza, Warszawa 2016.

Lach A., Rzetelne postępowanie dowodowe w sprawach karnych w świetle orzecznictwa strasburskiego, Warszawa 2018.

Murzynowski A., Istota i zasady procesu karnego, Warszawa 1994.

Nita B., Konstytucyjne zakorzenienie zasady nemo tenetur se ipsum accusare, [w:] Rzetelny proces karny. Księga jubileuszowa Profesor Zofii Świdy, red. J. Skorupka, Warszawa 2009.

Nowicki M.A., Wokół Konwencji Europejskiej. Komentarz do Europejskiej Konwencji Praw Człowieka, Warszawa 2017.

Nowikowski I., Uwagi o zasadzie rzetelnego procesu (kwestie wybrane), [w:] Rzetelny proces karny. Księga jubileuszowa Profesor Zofii Świdy, red. J. Skorupka, Warszawa 2009.

Pradel J., Rzetelny proces w europejskim prawie karnym, „Prokuratura i Prawo” 1996, nr 9.

Rainey B., Wicks E., Ovey C., The European Convention on Human Rights, Oxford 2017.

Skorupka J., Cele procesu karnego, [w:] System Prawa Karnego Procesowego, t. 1, cz. 1. Zagadnienia ogólne, red. P. Hofmański, Warszawa 2013.

Skorupka J., Proces karny, Warszawa 2018.

Skorupka J., Sprawiedliwość proceduralna jako cel procesu karnego, [w:] Rzetelny proces karny. Ksiega jubileuszowa Profesor Zofii Świdy, red. J. Skorupka, Warszawa 2009.

Szumiło-Kulczycka D., Zasada sprawności (szybkości) i zasada koncentracji materiału dowodowego, [w:] System Prawa Karnego Procesowego, t. 3, cz. 2. Zasady procesu karnego, red. P. Wiliński, Warszawa 2014.

Szydło M., [w:] Konstytucja RP. Komentarz, t. 1. Art. 1-86, red. M. Safjan, L. Bosek, Warszawa 2016.

Tuleja P., [w:] Konstytucja Rzeczypospolitej Polskiej. Komentarz, red. P. Tuleja, Warszawa 2019. Waszczyński J., O przygotowaniu obrony, „Palestra” 1966, nr 8.

Wiliński P., Proces karny w świetle Konstytucji, Warszawa 2011.

Wiliński P., Sprawiedliwość proceduralna a proces karny, [w:] Rzetelny proces karny. Księga jubileuszowa Profesor Zofii Świdy, red. J. Skorupka, Warszawa 2009.

Wiliński P., Zasada prawa do obrony w polskim procesie karnym, Kraków 2006.

Wiliński P., Karlik P., [w:] Konstytucja RP. Komentarz, t. 1. Art. 1-86, red. M. Safjan, L. Bosek, Warszawa 2016.

Zagrodnik J., Obrońca i petnomocnik w procesie karnym i karnym skarbowym, Warszawa 2020.

Zagrodnik J., Chmielniak Ł., Klonowski M., Rychlewska-Hotel A., [w:] Kodeks postępowania karnego. Komentarz praktyczny do nowelizacji 2019, red. J. Zagrodnik, Warszawa 2020. 